\title{
Research and Analysis of College Ideological and Political Course Based on Information Technology
}

\author{
Zhang Tianqi \\ Department of teacher education, Wuzhou University, Guangxi, China \\ Zhang452637@foxmail.com
}

\begin{abstract}
The rapid development of modern science and technology has pushed information technology into all areas of society, affecting people's ways of thinking, learning and behavior. Information technology has begun to be applied in various subject areas of education, providing convenient and effective teaching aids to better achieve the goal of subject teaching. At present, most of the teaching activities have been invested in information technology, and the application range of information technology in teaching has been expanding. This article analyzes the necessity and possibility of the deep integration of information technology and ideological and political education and proposes effective approaches to the problems existing in the integration of the two. The in-depth integration of ideological and political teaching improves the effectiveness of ideological and political teaching in colleges.
\end{abstract}

Keywords: Information technology, Ideological and political lessons, Integration

\section{Introduction}

With the popularization of education informatization, information technology has begun to be applied to various subject areas of education and has become a new teaching means to achieve teaching goals. The Ten-year Development Plan for Educational Informatization (2011-2020) issued by the Ministry of Education in 2012 proposed that one of the effective ways to promote higher education reform and innovation and improve quality is to focus on the integration of information technology and higher education. Some researches at home and abroad have made some progress, which has a reference role for further research. However, the current research on the integration of the two does not start from the in-depth analysis of the course nature of ideological and political courses in colleges and universities, and does not truly achieve a deep integration of the content of ideological and political course teaching and information technology in colleges and universities.

Educational informationization is a dynamic historical process. Based on the four-stage theory of the integration of information technology and education and teaching put forward by UNESCO in 2005, a comparative analysis of China's actual development status. You can further understand the integration and development of information technology and education and teaching. In recent years, the research on the integration of information technology and ideological and political lessons in colleges and universities has mainly focused on journals and a few related monographs. Most scholars believe that the essence of the integration of

Article history:

Received (January 14, 2020), Review Result (February 20, 2020), Accepted (April 2, 2020) 
information technology and ideological and political lessons in colleges and universities is to change the traditional teacher-centered teaching model, catalyze new teaching concepts, and generate new teaching models, rather than simply combining information technology and thinking Political lessons superimposed. In Liang Liang's "Discussion on Several Issues on the Integration of Information Technology and Ideological and Political Theory Teaching", we proposed that in the teaching of ideological and political courses, we cannot treat the "objective-content" relationship with "general methods". We must consider ideological and political theories. The nature and characteristics of the lesson. In-depth analysis of the confused boundaries between multimedia teaching and multimedia courseware in ideological and political theory courses, and the conflicting theories and technical logics of learning from technology and learning from technology.

As an ideological course that integrates teaching, ethics, and building people, the ideological and political course in colleges and universities should be in line with the development of the times, actively integrate and integrate with information technology, and form a new teaching form. Therefore, the ideological and political courses in colleges and universities must adapt to the general trend of education informatization and integrate information technology into curriculum teaching. Contemporary college students are in an era of unprecedented development of information technology. Most channels for them to obtain information are through online access. This method is also the most popular learning method for contemporary college students. The traditional way of teaching ideological and political courses in colleges and universities has not been able to meet the psychological needs of students. Therefore, from the current point of view, the informationization of ideological and political teaching in colleges and universities has also become an irresistible trend. The integration of information technology and ideological and political education is not a simple addition of the two. Regardless of which dimension it starts from, its purpose is to change the traditional ideological and political education and teaching model and give full play to the leading role of teachers and students. Further promote the deep integration of the two and improve the effectiveness of ideological and political education.

\section{Feasibility of deep integration of information technology and ideological and political education in colleges}

The advent of the information age has pushed education and teaching into a new era. Education and teaching have also followed the pace of the times and entered a new era. A series of new teaching methods such as FLIP, mobile teaching, MOOK, and micro-learning have been introduced. The deep integration of information technology and ideological and political teaching in universities has certain possibilities. First, information technology as a technical means can achieve the complementation of the teaching goals of ideological and political lessons in colleges and universities, so that information technology can better serve the teaching goals of ideological and political lessons in colleges and universities. Secondly, information-based teaching form can be better. More effectively serve the teaching content of ideological and political lessons in colleges and universities, and the two are compatible with each other. Finally, the virtual space of information technology can further fit the actual environment of ideological and political lessons in colleges and universities, and improve the effectiveness of ideological and political lessons in colleges and universities. Promote the healthy development of information technology virtual spaces. 


\subsection{The necessity of deep integration of information technology and college ideological and political education}

The advent of the information age has made the impact of information technology on education and teaching deeper and closer, and the relationship between the two is getting closer. Various countries and regions are paying more and more attention to the integration of information technology and education. China's education industry has positioned its development strategy to drive education modernization with education informatization. In recent years, the Ministry of Education of China has repeatedly issued the implementation of informatization development policies, paid close attention to the implementation of various education tasks, and continuously increased the standardization of the implementation of informatization in education and teaching. To promote the development of education informatization. In 2012, in the "Ten-year Development Plan for Educational Informatization (2011-2020)", the practical concept of "deep integration of information technology and education and teaching" was first proposed [1]. In 2016, General Secretary Xi Jinping emphasized at the National College Ideological and Political Work Conference that it is necessary to use new media and new technologies to make work alive, promote the traditional integration of ideological and political work with information technology, and enhance the sense of the times and attractiveness. [2] In 2017, the "Implementation Outline for the Quality Improvement Project of Ideological and Political Work in Colleges and Universities" once again stated that "the traditional advantages of ideological and political work are highly integrated with information technology" [3].

Marx pointed out that "the development of technology will cause changes in production methods and social relations" [4]. From the traditional agricultural society to the machine industry era to the information technology era marked by modern information technology, the update of labor tools has gradually become an important indicator of the changing times. Information technology is infiltrated in different areas of society. In the field of education, information technology has greatly affected it. Education is essential in society. However, every change in education has a certain relationship with information technology. Information technology has broken the original teaching method and updated it. Educational philosophy, education methods. The ideological and political course in colleges and universities is the forefront of mainstream Marxist ideology. It undertakes the important task of disseminating mainstream Marxist ideology and guiding students to establish correct ideology. In the end, it is necessary to achieve the fundamental goal of "building people with virtue." Therefore, from the perspective of the educated person, the deep integration of the two adapts to the personalized development of contemporary college students Demand, increasing enthusiasm for students to further study this course.

\subsection{Possibility of deep integration of information technology and ideological and political education in colleges}

Teaching methods and goals complement each other and promote each other. In order to achieve teaching goals, it is inseparable from teaching methods to play an auxiliary role, and at the same time decide what kind of teaching methods to use, all the use of teaching methods is to better achieve the teaching goals. Information technology can serve as a new teaching method to better serve the teaching goals of ideological and political lessons, lead the mainstream ideology of Marxism, cultivate socialist successors, and finally achieve the teaching goal of "Lide Tree". The dialectical relationship between form and content shows that form and content are interdependent and promote each other. Proper use of form will 
promote the development of content, otherwise it will hinder the development of content. Correspondingly, the teaching of this course can further improve the information-based teaching form. In addition, the information technology virtual space can explore a wider field for the development of this course, expand the position on the original basis, and more effectively promote the development of this course.

Compared with other disciplines, the unique ideological, guiding and critical characteristics of ideological and political courses in colleges and universities are more prominent. In addition to the explicit goal of imparting theoretical knowledge of Marxism, one of its hidden goals is also the ultimate goal, that is, to achieve the "ethics", which determines the depth of the integration of information technology and ideological and political lessons. Other subjects. First, information technology provides an effective means for the dissemination of the mainstream ideology of Marxism in ideological and political courses in colleges and universities. Second, the realization of the teaching goals of ideological and political courses in colleges and universities is aided by and adapted to the new teaching method of information technology. Third, the critical and guiding decisions of ideological and political lessons in colleges and universities must make reasonable use of information technology. We can use information technology to obtain all the required teaching and learning resources. The resources on the Internet are mixed. How to use information technology to select available teaching and learning resources. This requires the critical and ideological education of colleges and universities. Guiding role to achieve the optimization of the integration of the two. At present, many schools use MOOCs for teaching. MOOCs, an online teaching method, provide teaching and learning resources to the greatest extent, and to a certain extent, share resources. Therefore, in the teaching process, teachers need to make appropriate use of information technology to screen resources for ideological and political lessons, guide students to use the Internet reasonably, use nutritional and healthy network knowledge, and criticize and prevent all ideological trends that depart from Marxism field.

\subsection{The virtual space of information technology is in line with the actual teaching environment of ideological and political lessons}

Technology is one of the most basic practical activities of human beings. Technology is established as a way of human existence, and it is a real bridge between humans and nature [5]. Whether it is information technology or education, it is to meet the emergence and development of social needs. The application of information technology to education largely reflects social needs. The integration of technology and teaching produces information-based teaching forms. The relationship between form and content is expressed in the five categories of Marxist theory. The two are interdependent. The form serves the content and promotes the development of the form. This requires that there must be new forms to present content, so we must constantly break the old forms, create new forms, and better serve the content. Compared with other courses, the mainstream ideology of Marxism in colleges and universities is more obvious. It is responsible for teaching Marxist theoretical knowledge and disseminating this mainstream ideology. Education leads students to establish correct concepts. The social trend of thought it leads must always keep pace with the times, and information-based teaching as a new form can better serve the teaching content of the course. First, the information-based teaching form, as a new teaching form, can better serve the teaching content of ideological and political courses in colleges and universities. Second, the teaching content of ideological and political courses in colleges and universities actively 
adapts to the information-based teaching form. The information-based teaching form can better meet their psychological needs for learning. Teachers can obtain the latest and most advanced theoretical knowledge through information technology, obtain more learning resources that can stimulate students' interest, and further organize them into teaching resources. Combining these teaching resources with Marxist theoretical knowledge and seeking a connection point between them not only satisfies the students' psychology of learning the latest knowledge, but also imparts course content. In this process, teachers should build an information-based teaching form according to the teaching requirements of ideological and political lessons, give play to the role of organization and guidance, give play to the charisma of personal mentoring and personal education, conduct emotional communication between teachers and students, and guide students to establish correct Values. The teaching content of ideological and political lessons and the information-based teaching form adapt to each other and promote each other. The teaching of the content should be adapted to this new teaching form. The new teaching form should better serve the teaching content of ideological and political lessons. There is me, you have me.

College students are in a critical period of extremely active thinking, strong curiosity, and value establishment. It is very important to have a correct guide to their life values. As a course that promotes the mainstream ideology of Marxism, ideological and political lessons in colleges and universities will inevitably have a psychological resistance to the course, which will weaken the effectiveness of ideological and political lessons. Therefore, teachers can be the first to access the Internet, learn about the latest developments in cyberspace, and treat the information in virtual space with a "bringing doctrine" attitude. Combining the teaching content of ideological and political lessons to guide students to use Marxist perspectives to view the information spread in virtual space, "take the essence and remove the dross", make reasonable use of teaching resources in learning cyberspace, and promote the virtuality of information space to ideological and political lessons The reality of the teaching environment is transformed, and the "Internet + ideological and political course" teaching model is truly promoted. Students can also strengthen communication with students and teachers through the virtual space of the network, so that students can have a deeper understanding and comprehensive understanding of what they have learned. At the same time, this network virtual space is Students have more opportunities to make autonomous choices.

\section{Difficulties in the integration of information technology and ideological and political teaching in colleges}

Compared with other basic courses and professional courses, college ideological and political courses have certain dualities. On the one hand, it plays an important role in imparting knowledge about Marxist theory in the knowledge system; on the other hand, ideological and political lessons in colleges and universities are core courses to help college students establish correct ideals, beliefs, and values of life. In the process of exploring how to better integrate ideological and political teaching with information technology, many new teaching models have emerged, such as mini-lectures, advocacy courses, flipped classrooms and simple classrooms. These teaching modes apply information technology to teach to a certain extent and realize resource sharing. In the process of the deep integration of the two, there are the problems of "two skins" of means and goals, the low degree of integration of form and content, and problems in the information literacy of ideological and political teachers in universities need to be further improved. 


\subsection{Disjointed phenomenon of fusion}

Under the guidance of modern technology, information technology is widely used as a new means in different fields. In the field of ideological and political teaching in colleges and universities, information technology has been enthusiastic for teachers as a teaching aid. Before class, teachers can use information technology to collect teaching materials that are related to the content of this lesson, and can also attract students' interest, and make corresponding teaching courseware; students can be mobilized to participate in the class during the class, and discuss the class Problems encountered; further exchanges and discussions between teachers and students on the online teaching platform after class, so that this lesson can be taught in a teaching method that is more interesting and acceptable to students, which can improve the effectiveness of teaching. But no matter what form it takes in the course of ideological and political lessons, it is used as ideological and political lessons. A supplementary means of teaching politics, with the purpose of serving the teaching goals of politics. Therefore, the teaching goals of ideological and political courses in colleges and universities and information technology methods complement each other and influence each other to jointly promote the effectiveness of this course.

But there is also a phenomenon of over-reliance on information technology to weaken the teaching goals of ideological and political lessons. College ideological and political lessons have clear teaching goals, impart basic Marxist theoretical knowledge, train students to establish correct ideals, beliefs, and values of life, and guide students to use Marxist basic viewpoints to analyze and solve problems. The ideological and political lessons must always focus on this. It is not feasible to carry out a teaching goal without any teaching means. According to relevant survey data on the application of information technology by university teachers, most and almost every class is teaching $74.08 \%$ with information technology, and about half account for $14.81 \%$. Few and almost no teachers account for $11.11 \%$ [6]. It can be shown that most teachers use information technology in the teaching process. The use of information technology in teaching is to better serve the teaching goals of ideological and political lessons. However, for the time being, many teachers do not have a good grasp of the relationship between information technology and ideological and political lessons. In the teaching process, many teachers of ideological and political lessons rely too much on information technology. In the course of preparing lessons, teachers put too much emphasis on information-based teaching, focusing on how to use information technology, focusing too much on the question of "how to teach", ignoring the question of "why to teach," and devoting a lot of energy Invest in the production of courseware. Information technology cannot play its due role.

\subsection{Formalization of information technology use in teaching}

At present, some teachers of ideological and political education have some deviations in their understanding and understanding of information technology, and the phenomenon of generalization and superficiality has appeared. The integration of information technology and ideological and political teaching is to effectively integrate teaching resources. In this process, ideological and political lessons are the mainstay. Information technology provides effective auxiliary means for teaching, better serves to teach, promotes the change of teaching methods, and ultimately improves the effectiveness of teaching. However, most teachers of ideological and political lessons have not systematically studied the relevant knowledge of information technology. They are not very familiar with the application of information technology in teaching. In daily ideological and political lessons, they simply use slide projectors, 
computers, etc. The teaching content is displayed on a computer, mistakenly thinking that this is an information-based teaching. Many colleges and universities have also blindly invested information and technology in teaching, and mistakenly believe that the use of information technology is a goal of the current curriculum. In fact, the use of information technology by some universities is not very good, and even the introduced information technology is put on hold. On the one hand, the role of information technology in improving teaching quality has not been brought into full play. On the other hand, part of the school's informatization construction is not actually a need for actual teaching, which has caused a waste of resources to some extent. In addition, some ideological and political teachers put some teaching resources on the computer platform, such as electronic lesson plans, electronic teaching materials, etc. Students obtain course resources through relevant links to achieve the so-called teaching informationization. But no matter which of the above methods, it is just the application of information technology in teaching, it is a combination, not a fusion. As a technical means, information technology also has a rich connotation. Ideological and political teaching can be used to promote new teaching methods and teaching ideas, and to better impart Marxist theoretical knowledge. Therefore, information technology is not a mere application in ideological and political teaching, nor is it a simple superposition of means and content. In this process, technical resources and teaching resources must be effectively combined to achieve the purpose of integration of the two.

\section{Ways to deeply integrate information technology and college ideological and political course teaching}

The deep integration of information technology and ideological and political lessons in universities emphasize the use of information technology as a carrier, combining the characteristics of curriculum and technical means, to integrate information technology into ideological and political lessons in universities, and also to integrate ideological and political lessons in information technology Two-way fusion.

\subsection{Constructing integrated teaching concepts}

It is clear that the goal of the deep integration of information technology and ideological and political teaching in colleges and universities is the basis and prerequisite for effective integration of the two. In the process of integration of the two, we must adhere to the guiding position of Marxism, and we must maintain a correct value orientation and class stand. On the one hand, promoting the deep integration of the two is to further promote the development and improvement of this course. On the other hand, to promote the deep integration of information technology and ideological and political lessons in colleges and universities is to use information technology to improve the affinity and pertinence of ideological and political lessons, and to better implement the teaching goals of "Lide Tree". In addition to "learning" in ideological and political courses in colleges, the most important thing is to "educate people". It is necessary to guide and cultivate the correct concepts of educated people. To achieve such teaching effects, one cannot rely solely on the teaching of professors. Nor can we rely solely on the learning of the educated, and we must form the concept of "putting equal emphasis on learning and teaching". Lecturers can learn from new technical methods, take into account the advantages of traditional ideological and political courses, create a good information-based teaching environment, and guide students to learn autonomously in this environment. 
First, to further promote the construction and development of ideological and political courses in universities. The ideological and political discipline construction plays an important role in strengthening the further development of the discipline. It is an important basis for strengthening and improving this course. Therefore, it is necessary to continuously follow up the discipline construction. General Secretary Xi Jinping proposed that we should promote the construction of ideological and political lessons as a whole, rely on innovation, promote continuous reform of teaching, strengthen the combination of traditional and practical teaching, and improve classroom efficiency. The deep integration of information technology and ideological and political education can promote the construction and development of this course. Secondly, use information technology to improve the affinity and pertinence of ideological and political lessons, and achieve the teaching goal of "ideological people" in ideological and political lessons. The ideological and political course in colleges and universities must always adhere to the fundamental task of establishing a good person, and carry out specific teaching around this fundamental goal, reflecting that it is a very important course as an education of socialist core values. In addition, the country also attaches more and more importance to the comprehensive development of educated people in all aspects, truly combines their growth laws with the needs of society, focuses on reflecting the current preferences of students, and takes the educated people's inner needs as the starting point. Reconcile and refine the main content taught. Improving the affinity of ideological and political classes emphasizes that students are the center. Teachers should make good use of information technology as a teaching method to motivate students to take the initiative to learn. The deep integration of information technology and the course emphasizes the guidance of professors and the educated Initiative, change the traditional way of "full house" in teaching, truly allow students to participate in the classroom, allow students to change from the original "unwilling to learn" to "I want to learn", and effectively implement the goal of "building people", highlighting the effectiveness of ideological and political lessons.

\subsection{Construction of "Internet + Ideological and Political Course" teaching mode}

Under the influence of curriculum informatization, new models of "Internet + Education" are gradually being developed in universities, and many new teaching models continue to appear, providing a driving force for the widespread development of the "Internet + Ideological and Political Education" teaching model. Minister Chen Baosheng proposed that the ideological and political work of colleges and universities should be combined online and offline. We must make good use of technical means and network positions online to continuously provide effective teaching resources to the educated. Offline is to give full play to the role of various activity carriers, so that they can give full play to their own functions. This is to make good use of the role of the Internet. The lecturer continuously enriches teaching resources through the Internet. Students can also obtain some online teaching resources and teaching guidance through the Internet to complete a series of knowledge theory learning. Offline fully reflects the leading role of ideological and political class teachers, answering questions and doubts about educated students' online learning, and no longer repeating relevant theoretical knowledge. Then, in this process, the teacher should carry out a detailed analysis of the problems encountered, and truly realize the purpose of "internalizing the heart and externalizing the knowledge" of the knowledge, thereby improving the effectiveness of teaching.

Online education and offline education are like twin brothers. Both are indispensable. Offline education is an important foundation for online education. To make the best use of 
online education, the foundation of offline education must be firmly established. At present, many public accounts and micro-lectures related to ideology and politics have been launched one after another. Research on subject and object and discourse of ideological and political education on the Internet has also become popular. Research is just a different new form of ideological and political education, and it must follow its own characteristics and overall laws to lay a solid foundation offline. Offline ideological and political education first grasps the teaching needs, and promotes the development of online education on the basis of grasping the basic teaching requirements. Contemporary college students have become accustomed to using the Internet as an important channel for them to access new things and learn new things. Teachers must grasp the learning needs of students and use information technology as a means to transform abstract and theoretical knowledge into a Teaching in a more visual and intuitive way.

Integrate and optimize online teaching resources. Information technology, represented by new technologies such as network information technology, artificial intelligence, and virtual reality, has promoted the transformation of society into an information society, and has promoted the transformation of education and teaching to information. The continuous infiltration of information technology in the teaching field has promoted the informatization of ideological and political teaching. Online ideological and political education is a form of education that uses online education as a platform for its related teaching. On the basis of offline, it is keeping pace with the times and doing online work accordingly. The ideological and political course in colleges and universities always adheres to the mainstream ideology of Marxism and adheres to the guidance of socialist core values. For online teaching resources, the online teaching platform should screen effective resources that can promote the core values of socialism, abandon all kinds of bad resources that deviate from the mainstream ideology, and strengthen the communication and sharing of online teaching resource platforms with relevant platforms inside and outside the school. Course Effectiveness Resources.

\subsection{Improving teachers' information literacy and promoting the development of informatization of ideological and political education}

The widespread application of information technology in education has brought more reform and development opportunities to education. In many cases, the effect of the implementation of informatization education is determined by whether the teaching behavior of the professor can be changed. Teachers are the concrete implementers of the effective application of information technology in teaching. The effect of the implementation of information technology in ideological and political lessons depends to a certain extent on the teaching behaviors of ideological and political lessons. In April 2018, the Education Informationization 2.0 Action Plan pointed out that the revolutionary impact of information technology on education has begun to appear, but there is still a large gap with the requirements of the new era. For example, the level of development and service of digital education resources is insufficient, and the information quality of teachers is not high enough. In response to these problems, the Ministry of Education also proposed special measures to improve the information literacy of teachers and students. How to effectively train the relevant skills of ideological and political class teachers and improve their information quality is a top priority. Informatization education has largely emphasized that the educated person is the center and the teacher plays a leading role. On the one hand, it is necessary to change the teaching concept of ideological and political teachers, strengthen the study of theory and 
skills, and improve the information teaching ability of professors. On the other hand, we need to build a teacher-student communication platform and two-way interaction to better promote the development of teaching informationization of this course.

\section{Conclusion}

As a cutting-edge course of the mainstream ideology of Marxism, the ideological and political course in colleges and universities not only undertakes to impart basic theoretical knowledge of Marxism, but also bears the heavy responsibility of guiding students to establish correct world outlook, outlook on life, and values, and training students to form a good ideological and moral cultivation. The affinity and pertinence of ideological and political lessons really stimulate students' enthusiasm for ideological and political lessons. This requires the integration of information technology and ideological and political lessons in colleges and universities to grasp the psychological and learning characteristics of students. Following the basic rules of ideological and political course teaching, starting from the nature of the ideological and political course and the characteristics of information technology, analyze the relationship between the ideological and political course teaching goals and information technology means, the ideological and political course teaching content, and the information-based teaching form. Seeking the meeting point and balance point between the two, the ultimate goal is to cultivate college students "correct world outlook. Construct new concepts of "learning" and "teaching" and improve the teaching model of "Internet + Ideological and Political Course". Strengthen the integration of online and offline, and continuously improve the information literacy of ideological and political teachers in universities.

\section{References}

[1] Chen Liyan, "Investigation and research on the information technology application ability of college teachers in fujian province," Journal of Jimei University (Education Science Edition), vol.17, no.02, pp.25-31, (2016)

[2] Gu Xiaochuan. "Analysis of the current situation and countermeasures of internet ideological and political education in colleges and universities," Contemporary Educational Practice and Teaching Research, no.09, pp. $10-11+15$, (2018)

[3] Guo Haicheng, "Application and prospect of new media and new technology in the teaching of ideological and political theory courses in colleges and universities - taking "Rain Classroom" as an example," Journal of Heilongjiang College of Education, vol.37, no.02, pp.42-44, (2018)

[4] Jin Jing, "Research on the teaching reform of ideological and political theory courses in higher vocational colleges under the environment of information technology," Journal of Hunan Vocational College of Posts and Telecommunications, vol.16, no.03, pp.128-130, (2017)

[5] Li Jianyong and Chen Guoqing, "The integrative development of ideological and political theory courses and new media and new technology in colleges and universities: achievements, problems and solutions," Journal of Social Science of Shanxi Colleges and Universities, vol.29, no.06, pp.42-45, (2017)

[6] Peng Liusheng, "An analysis of ideological and political education in colleges and universities by using network information technology,” Farm Staff, no.15, pp.186-187, (2018) 